\title{
INVESTIGATION OF THE INHIBITIVE PROPERTIES OF MANGIFERA INDICA (MANGO) SEED EXTRACT ON ALUMINUM METAL CORROSION IN 0.5M HCL MEDIUM
}

\author{
Ekeke, I. C., Olubiyi S. O., Obasi, E. E., Nzeoma, C., Anyikwa, S. O., Uzoma, H. C and. Ngolube, B. C. \\ Department of Chemical Engineering, Federal University of Technology, \\ Owerri, Imo State, Nigeria.
}

\begin{abstract}
Mangifera indica (Mango) seed extract was examined as corrosion inhibitor for aluminum in hydrochloric acid medium. The inhibition properties of the extract were investigated using gravimetric method in the form of a prolonged period of experimentation ( 21 days) and a rapid period of experimentation (5 hours). Inhibitor concentration $(0.2 \mathrm{~g} / \mathrm{L}-1.0 \mathrm{~g} / \mathrm{L})$ and time were the considered factors at ambient temperature. In the case of the prolonged test, variation of weight loss was monitored periodically in $0.5 \mathrm{M} \mathrm{HCl}$ medium in the presence of the different concentrations of the inhibitor and its absence. The weight loss was calculated in grams as the difference between the initial weight and the weight after the removal of the corrosion product. In the rapid test case, air was introduced in the acidic medium and weight loss measurements also taken after the experiment. The concentration of extract with the highest inhibition efficiency for the prolonged test experiment was $0.4 \mathrm{~g} / \mathrm{L}$, with an efficiency of $95.31 \%$ recorded while the highest inhibition efficiency value for the rapid test case was $93.68 \%$ recorded for the $1.0 \mathrm{~g} / \mathrm{L}$ concentration. However, most of the efficiency values obtained in the former were low compared with those obtained in the latter. This shows that Mangifera indica seed extract better inhibited the corrosion of aluminum in hydrochloric acid during the rapid test.
\end{abstract}

Keywords - Corrosion, Inhibitor, Mangifera indica, Aluminum, Hydrochloric acid

\section{INTRODUCTION}

Corrosion is a natural process, which converts a refined metal to a more chemically-stable form, such as its oxide, hydroxide, or sulfide. It is the gradual destruction of materials (usually metals) by chemical and/or electrochemical reaction with their environment. In the most common use of the word, this means electrochemical oxidation of metals in reaction with an oxidant such as oxygen or sulfates. Rusting, the formation of iron oxides is a well-known example of electrochemical corrosion. This type of damage typically produces oxide(s) or salt(s) of the original metal, and results in a distinctive orange coloration. Many structural alloys corrode merely from exposure to moisture in air, but the process can be strongly affected by exposure to certain substances. Corrosion can be concentrated locally to form a pit or crack, or it can extend across a wide area more or less uniformly corroding the surface. Because corrosion is a diffusion-controlled process, it occurs on exposed surfaces. Corrosion can only be reduced significantly or delayed to a reasonable extent. Controlling of the $\mathrm{pH}$ or ion concentration of the solution or controlling the metal solution interface had a number of ways to achieve the reduction in the rate of corrosion over the years. Obot et al (2011) asserted that this is achieved through the addition of small quantity of chemicals called inhibitors that either encourage film formation or form a barrier - like layer on the metal surface and by so doing stop or slow down the rate of metal decomposition.

Aluminum had been seen as one of the most important metals in the electrochemical series, not just because it can be alloyed with almost any metal but also because of its wide usability and reasonable level of resistance to corrosion. By mass, aluminum makes up about $8 \%$ of the Earth's crust; it is the third most abundant element after oxygen and silicon and the most abundant metal in the crust, though it is less common in the mantle below. Notwithstanding its ability to resist corrosion, aluminum metal still corrodes in the presence of moisture and even faster in acidic medium $(\mathrm{HCl})$. Difficulties have been noticed in the corrosion of aluminum metal in aerospace industry, transportation and building industries. Research has shown that metals corrode faster in the presence of acidic media than water or natural moisture. This is due to the fact that, the lower the $\mathrm{pH}$ value of the medium, the higher the corrosion rate.

Benali et al ((2013) reported that throughout the ages, plants have been used by human beings for their basic needs such as shelter, production of food stuffs, fertilizers, flavors and fragrance, clothing, medicines and last but not the least, as corrosion inhibitors. The use of corrosion inhibitors is the most economical and practical method in reducing corrosive attack on metals. Lebrini et al (2011) defined corrosion 


\section{International Journal of Engineering Applied Sciences and Technology, 2020 \\ Vol. 5, Issue 4, ISSN No. 2455-2143, Pages 515-520}

Published Online August 2020 in IJEAST (http://www.ijeast.com)

inhibitors as chemicals, either synthetic or natural which when added in small quantity to an environment, decrease the rate of attack by the environment on metals. Most organic inhibitors are of plant origin and incredibly rich source of natural chemical compounds that can be extracted by very simple procedure with low cost. They are also biodegradable in nature. The natural plant extracts contain varieties of organic compounds, for example, amino acids, alkaloids, steroids, flavonoids, proteins and tannin as a green alternative for toxic and hazardous compounds.

Mangifera indica (mango) has been seen as one of the plants that can be used as a corrosion inhibitor. Studies have shown that mango has a high amount of antioxidants. It is packed with polyphenols - plant compounds that function as antioxidants. Corrosion inhibition studies have been done using the leaves (Loto 2001; Loto et al, 2003; Ugi et al 2015; Ramezanzadeh et al ,2019; Veedu et al, 2019) , bark (Loto 2001; Loto et al, 2003), seeds (Okoye et al, 2015) and peels (da Rocha et al, 2014; Udnne, 2015) of Mangifera indica. To the knowledge of the authors of this work, there has not been any report on the use of the seed extract of Mangifera indica as corrosion inhibitor for aluminum.

\section{EXPERIMENT AND RESULT}

Materials

Inhibitor: Mango Seeds Extract

Apparatus Used: Beakers/plastic containers, Brush, Electronic Weighing Balance, Manual weighing balance, Spatula, Round bottom flask, Grinder, Masking tape, Measuring cylinders, Aluminum coupons, Retort Stands, Round-bottom flasks, Heating mantle, Reflux set up, Handkerchief, Volumetric flask, Syringe, Brush, Knife, Sandpaper, Corrosion study kit.

Reagents: Analytical grade Hydrochloric acid, Acetone, Analytical grade ethanol, Water, Sodium

\section{Methods}

Materials Preparation: The aluminum coupons of dimensions $30 \mathrm{~mm} \times 30 \mathrm{~mm} \times 2 \mathrm{~mm}$ were obtained from Mechanical Engineering Department workshop, Federal University of Technology, Owerri (FUTO). They were smoothened with sandpaper, soaked in acetone and further cleaned using a brush. The coupons were weighed afterwards before dipping into the acidic medium.

Preparation of Extract: The mango seeds were sourced at FUTO. The shells were removed and the inner parts of the seeds were broken into bits and eventually dried using a drying oven at a temperature of $101^{\circ} \mathrm{C}$ for three days. The dried seeds were further ground into powder using a mechanical grinder. Two hundred grams (200g) of ground seeds were dissolved in $200 \mathrm{ml}$ of ethanol (extraction solvent), and the solution placed in the reflux setup. The setup was allowed to run for two (2) hours. This procedure was carried out five times, extracting all the powdered mango seed and producing an extract of $1 \mathrm{~g} / \mathrm{L}$ concentration. More concentrations $(0.2 \mathrm{~g} / \mathrm{L}, 0.4 \mathrm{~g} / \mathrm{L}, 0.6 \mathrm{~g} / \mathrm{L}, 0.8 \mathrm{~g} / \mathrm{L})$ were also prepared. Five inhibitor test samples were then prepared by dissolving $0.2 \mathrm{~g} / \mathrm{L}, 0.4 \mathrm{~g} / \mathrm{L}, 0.6 \mathrm{~g} / \mathrm{L}, 0.8 \mathrm{~g} / \mathrm{L}$ and $1.0 \mathrm{~g} / \mathrm{L}$ of the extract in $400 \mathrm{ml}$ of $0.5 \mathrm{M} \mathrm{HCl}$ respectively.

\section{Gravimetric (Weight Loss) Method of Analysis}

The Prolonged Test: The experiment was carried out at room temperature. Seed extracts with concentrations of $0.2 \mathrm{~g} / \mathrm{L}$, $0.4 \mathrm{~g} / \mathrm{L}, 0.6 \mathrm{~g} / \mathrm{L}, 0.8 \mathrm{~g} / \mathrm{L}$ and $1.0 \mathrm{~g} / \mathrm{L}$ were each dissolved in $400 \mathrm{ml}$ of the $0.5 \mathrm{M} \mathrm{HCl}$ acid solution contained in five different containers in which two metal coupons (already weighed) were immersed. Two other coupons were also immersed in $400 \mathrm{ml}$ of $0.5 \mathrm{M} \mathrm{HCl}$ blank solution (containing no inhibitor). The coupons were retrieved at intervals of 2 days for 21 days after which they were soaked in acetone, dried, sandpapered to remove the corroded particles, cleaned and then re-weighed. The weight lost was taken as the difference between the initial weight and the weight at any given time of observation.

The weight loss data gathered were then used to determine the corrosion rates and inhibition efficiencies.

Weight loss = Initial weight - Final weight

$W_{L}=W_{i}-W_{F}$

where $W_{L}=$ weight loss $(g), W_{i}=$ initial weight $(g)$, $W_{F}=$ final weight $(g)$

The weight loss determined was used to determine the corrosion rate according to the following equation:

$\mathrm{CR}=W_{L}$ At

where, $\mathrm{CR}=$ corrosion rate $\left(\mathrm{gcm}^{2}\right.$ day),

$\mathrm{A}=$ area of coupon $\left(\mathrm{cm}^{2}\right), \mathrm{t}=$ time (days)

The surface coverage, $\theta$ is given by equation (3):

$$
\theta=\frac{C R_{\text {blank }}-C R_{\text {inh }}}{C R_{\text {blank }}}
$$

where, $C R_{\text {blank }}=$ corrosion rate of solution without inhibitor ( $\mathrm{gcm}^{2}$ day)

$C R_{\text {inh }}=$ corrosion rate of solution with inhibitor ( $\left.\mathrm{gcm}^{2} \mathrm{day}\right)$

Inhibition efficiency I.E (\%) was evaluated from equation (4):

$$
\text { I. } \mathrm{E}=\frac{C R_{\text {blank }}-C R_{\text {inh }}}{C R_{\text {blank }}} x 100
$$

Rapid Test: The initial weights of the coupons were obtained using a weighing balance. The corrosion media (with and without the extracts) were placed in the corrosion kit. The coupons were placed in the media and air was passed through the media by the aid of the suction motor in the corrosion kit. The media experienced turbulence due to the air passing through them at low pressure. The set up was allowed to stand for an hour. The coupons were subsequently removed, dried, 


\section{International Journal of Engineering Applied Sciences and Technology, 2020 Vol. 5, Issue 4, ISSN No. 2455-2143, Pages 515-520 \\ Published Online August 2020 in IJEAST (http://www.ijeast.com)}

cleaned, sandpapered and reweighed. This procedure was repeated four more times.

\section{EXPERIMENT RESULT AND DISCUSSION}

Prolonged Test Results

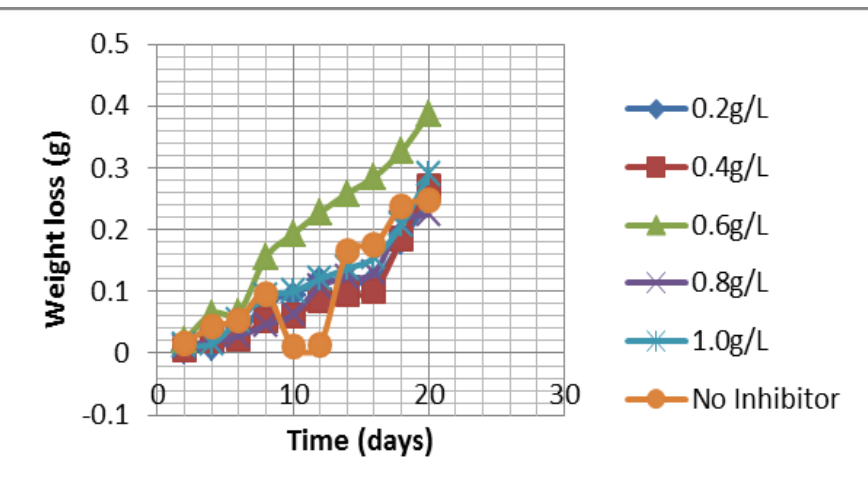

Figure 1: Weight loss against time for different concentrations of inhibitor

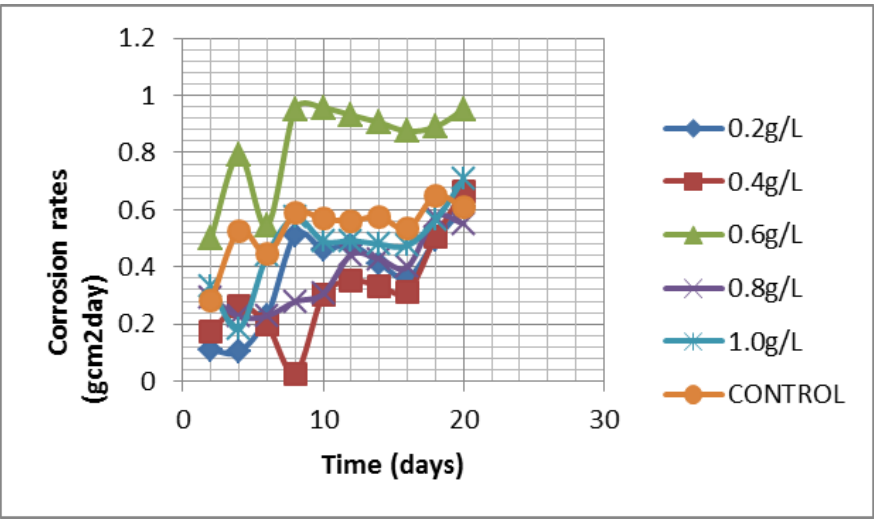

Figure 2: Corrosion rate against time for different concentrations of inhibitor

Table 1: Inhibition Efficiencies

\begin{tabular}{|l|l|l|l|l|l|}
\hline \multirow{2}{*}{$\begin{array}{l}\text { Time } \\
\text { days })\end{array}$} & \multicolumn{5}{|l}{ INHIBITION EFFICIENCY $(\%)$} \\
\hline 2 & $60.2 \mathrm{~g} / \mathrm{L}$ & $0.4 \mathrm{~g} / \mathrm{L}$ & $0.6 \mathrm{~g} / \mathrm{L}$ & $0.8 \mathrm{~g} / \mathrm{L}$ & $1.0 \mathrm{~g} / \mathrm{L}$ \\
\hline 4 & 80.23 & 39.13 & -78.26 & -4.35 & -17.39 \\
\hline 6 & 48.62 & 55.00 & -50.00 & 56.98 & 65.12 \\
\hline 8 & 13.02 & 95.31 & -61.98 & 52.60 & 02.60 \\
\hline 10 & 18.53 & 46.98 & -68.10 & 46.12 & 13.79 \\
\hline 12 & 14.91 & 37.45 & -65.82 & 21.10 & 12.36 \\
\hline 14 & 28.27 & 41.95 & -57.14 & 25.84 & 16.72 \\
\hline 16 & 32.18 & 41.38 & -64.08 & 25.00 & 10.92 \\
\hline
\end{tabular}

\begin{tabular}{|l|l|l|l|l|l|}
\hline 18 & 23.90 & 22.22 & -37.11 & 11.53 & 13.21 \\
\hline 20 & 0.00 & -09.27 & -56.25 & 09.27 & -16.53 \\
\hline
\end{tabular}

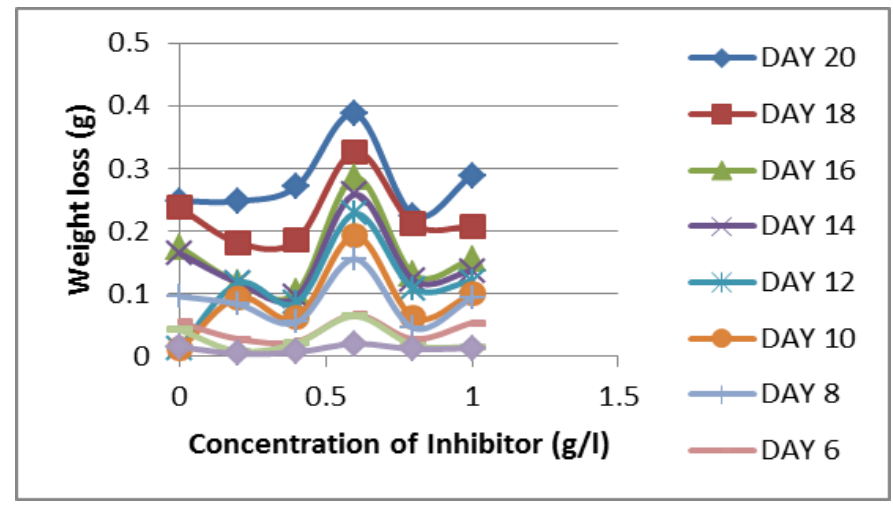

Figure 3: Weight loss against concentration of extract for each day of observation

\section{Rapid test results}

The readings were taken for two coupons per concentration and the average weight loss plotted in Figure 4.

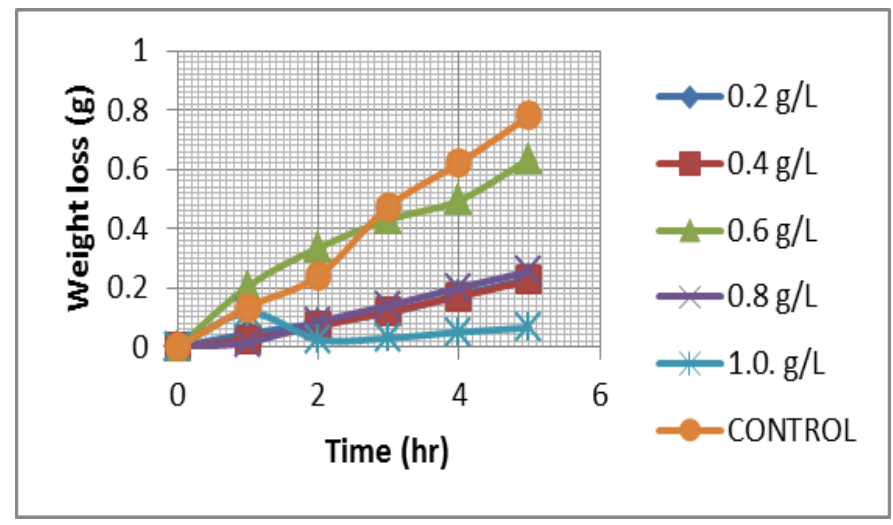

Figure 4: Weight loss against time at different concentrations of inhibitor (Rapid test) 


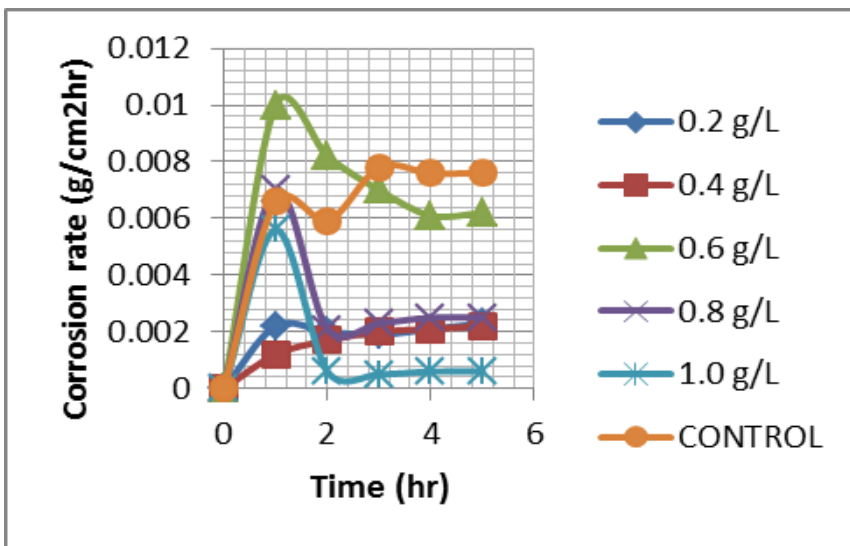

Figure 5: Corrosion rate of coupons against time

Table 2: Inhibition efficiencies for the rapid test

\begin{tabular}{|l|c|c|c|c|c|}
\hline \multirow{2}{*}{$\begin{array}{l}\text { Time } \\
\text { hr })\end{array}$} & \multicolumn{5}{|l}{ INHIBITION EFFICIENCY $(\%)$} \\
\cline { 2 - 6 } & $0.2 \mathrm{~g} / \mathrm{L}$ & $0.4 \mathrm{~g} / \mathrm{L}$ & $0.6 \mathrm{~g} / \mathrm{L}$ & $0.8 \mathrm{~g} / \mathrm{L}$ & $1.0 \mathrm{~g} / \mathrm{L}$ \\
\hline 1 & 66.67 & 81.48 & -51.85 & 88.89 & 14.81 \\
\hline 2 & 66.67 & 70.83 & -39.58 & 64.58 & 89.58 \\
\hline 3 & 75.79 & 74.74 & 9.47 & 70.53 & 93.68 \\
\hline 4 & 71.77 & 72.58 & 20.16 & 67.74 & 91.94 \\
\hline 5 & 70.51 & 71.15 & 18.59 & 67.31 & 91.67 \\
\hline
\end{tabular}

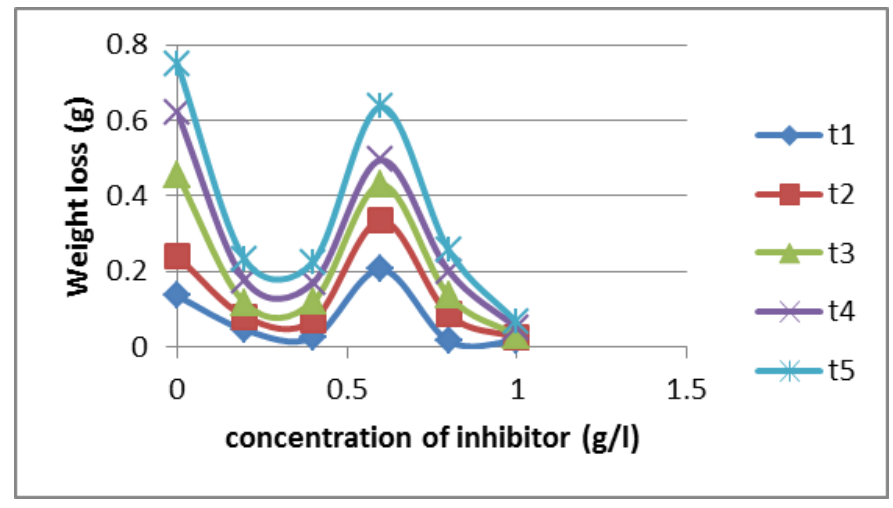

Figure 6: Weight loss against concentration of extract for each time

\section{Prolonged test Analysis}

Effect of Immersion Period on Weight Loss of Coupons Figure 1 shows the average weight loss of coupons at different immersion times and for different concentrations of the corrosion inhibitor as well as that of the blank acidic medium (control). The figure shows that the weight loss increased as the period of immersion increased, showing the coupons were corroding. However, it is observed that the weight loss experienced by the coupons in the control was higher than those for specimen immersed in inhibitor (except for the $0.6 \mathrm{~g} / \mathrm{L}$ concentration) though it reduced between the eighth and the twelfth day after which it began to rise again. The figure also shows that, for $0.6 \mathrm{~g} / \mathrm{l}$ extract concentration, the weight loss was abnormally high. This may be because, at $0.6 \mathrm{~g} / \mathrm{L}$ (under the conditions applied in the present work), the extract behaved as a poor inhibitor. Generally, the weight loss values in all the media were relatively low. This may be because of the position of aluminum metal in the electrochemical series. Aluminum is far from hydrogen in the electrochemical series; therefore it is not easily susceptible to oxidation (corrosion) in $\mathrm{HCl}$ compared to some metals. In addition, some of the weight loss - time patterns seen in Figure 1 are almost similar to some of those presented by Nwosu et al (2014) in their work.

\section{Effect of Immersion Period on Corrosion Rate}

Figure 2 shows the relationship between the corrosion rates of coupons and times of immersion for the blank acidic solution and at different concentrations of the corrosion inhibitor. It is observed that the corrosion rate increased as the immersion time increased though there was a decrease on the fourth day for the $0.2 \mathrm{~g} / \mathrm{L}$ and the $1.0 \mathrm{~g} / \mathrm{L}$ concentrations, on the $6^{\text {th }}$ day for the $0.6 \mathrm{~g} / \mathrm{L}$ concentration and the control, on the $8^{\text {th }}$ day for .the $0.4 \mathrm{~g} / \mathrm{L}$ concentration and on the $16^{\text {th }}$ day for all the concentrations and the control sample. Ghadal and Alshabana (2017) reported that weakness of the inhibitor with time might be a possible reason for this. It may also be as a result of dissolution of the inhibitor in the acidic medium as time of immersion increases. This reduces the effectiveness of the inhibitor and hence, increases its corrosion rate with increasing time of immersion. Another cause of this may be the attack of the acid on the coating formed by the inhibitor on the surface of the metal.

\section{Effect of immersion period on Inhibition Efficiency}

The relationship between inhibition efficiency and the period of immersion of coupons is seen in Table 1. On the 2nd day of observation, the inhibition efficiency values recorded for the $0.2 \mathrm{~g} / \mathrm{L}$ and $0.4 \mathrm{~g} / \mathrm{L}$ concentrations were $60.87 \%$ and $39.13 \%$ respectively. The values for the $0.6 \mathrm{~g} / \mathrm{L}, 0.8 \mathrm{~g} / \mathrm{L}$ and $1.0 \mathrm{~g} / \mathrm{L}$ concentrations were all negative. On the $4^{\text {th }}$ day of observation, the efficiency values for the $0.2 \mathrm{~g} / \mathrm{L}, 0.4 \mathrm{~g} / \mathrm{L}$, $0.6 \mathrm{~g} / \mathrm{L}, 0.8 \mathrm{~g} / \mathrm{L}$ and $1.0 \mathrm{~g} / \mathrm{L}$ increased to $80.23 \%, 50.00 \%$, $50.00 \%, 56.98 \%$ and $65.12 \%$ respectively. Subsequently, the values fluctuated (i.e. increased and then decreased at varying intervals of time) until the last day when the least values were recorded. The results, in summary, show that the highest inhibition efficiency value was obtained for the $0.4 \mathrm{~g} / \mathrm{L}$ concentration while the least was obtained for the $0.6 \mathrm{~g} / \mathrm{L}$ concentration. This suggests that Mangifera indica seed extract can only perform relatively well as a corrosion inhibitor for aluminum metal at low concentrations (about 


\section{International Journal of Engineering Applied Sciences and Technology, 2020 \\ Vol. 5, Issue 4, ISSN No. 2455-2143, Pages 515-520 \\ Published Online August 2020 in IJEAST (http://www.ijeast.com)}

$0.4 \mathrm{~g} / \mathrm{L}$ ) under the conditions considered in this work. Loto et al (2015) reported a similar result for the corrosion inhibition of mild steel reinforcement in concrete in $0.2 \mathrm{M} \mathrm{H} \mathrm{H}_{2} \mathrm{SO}_{4}$ medium using Vernonia Amigdalina extract and zinc oxide inhibitor.

\section{Effect of concentration on weight loss}

Figure 3 shows the plots of weight loss against concentration at different periods of observation. The highest weight loss occurred with the $0.6 \mathrm{~g} / \mathrm{L}$ concentration at all periods of observation.

\section{Rapid test Analysis}

\section{Effect of immersion Period on Weight Loss of Coupon}

Figure 4 shows the average weight loss at various periods of immersion for the rapid test. The result reveals that the weight losses of the coupons in the blank acidic solution (control) are relatively higher than those with inhibitors at their respective periods of immersion. This indicates that the seed extract inhibited the effect of corrosion on the aluminum metal. It also shows that the weight loss increased linearly as the period of immersion increased. However, inhibitor with concentrations of $0.2 \mathrm{~g} / \mathrm{L}$ and $0.4 \mathrm{~g} / \mathrm{L}$ show the same graph pattern as their weight losses at different immersion periods are approximately the same. At the end of the experiment (after 5 hours), among the samples containing the inhibitor, the least weight loss was obtained with the $1.0 \mathrm{~g} / \mathrm{L}$ concentration while the highest weight loss was recorded with the $0.6 \mathrm{~g} / \mathrm{L}$ concentration. This result indicates that the inhibitor was most efficient at a concentration of $1.0 \mathrm{~g} / \mathrm{L}$ and least efficient at a concentration of $0.6 \mathrm{~g} / \mathrm{L}$. It was also observed that all the coupons increased in weight losses almost linearly with time except the coupon immersed in inhibitor concentration of $1.0 \mathrm{~g} / \mathrm{L}$ which increased linearly after 2 hours. Also, the change in weight loss was least at $1.0 \mathrm{~g} / \mathrm{L}$ inhibition.

\section{Effect of immersion period on Corrosion Rate}

The corrosion rate at various periods of immersion for various concentrations of inhibitor is seen in Figure 5. From Figure 5, it is seen that the corrosion rates had high increase from 0 to 1 hour of immersion but dropped sharply between the 1st and the 2 nd hours of immersion, except for inhibitor with $0.4 \mathrm{~g} / \mathrm{L}$ extract concentration, which increased almost linearly throughout the 5 hours of immersion. In fact, the highest corrosion rates are observed at about the 1 st hour for all inhibited samples. The corrosion rates became almost constant after 3 hours except for the inhibitor with $0.6 \mathrm{~g} / \mathrm{L}$ concentration of the extract and that of the blank acidic medium which reduced. The $0.6 \mathrm{~g} / \mathrm{L}$ concentration of the extract is observed to have the highest corrosion rate among all the inhibited experiments. This correlates with the prolonged test method of analysis where it was seen that at $0.6 \mathrm{~g} / \mathrm{L}$ concentration of extract, the extract exhibited low inhibition of corrosion. However, for $1.0 \mathrm{~g} / \mathrm{L}$ concentration of extract, the corrosion rate is relatively low and reduced with increasing time and then became stable after 3 hours. This indicates that, at this concentration of extract, the corrosion inhibition activity increased with increasing time to an extent. This may be due to the action of larger amount of molecules in the extract, covering many surfaces and gradually reducing the corrosion rate. Concentrations of $0.2 \mathrm{~g} / \mathrm{L}, 0.4 \mathrm{~g} / \mathrm{L}$, and $0.8 \mathrm{~g} / \mathrm{L}$ also showed low corrosion rates relative to that of $0.6 \mathrm{~g} / \mathrm{L}$ and the blank acidic solution.

\section{Effect of immersion period on Inhibition Efficiency}

Values of inhibition efficiency at different times for each concentration are shown in Table 2. The table shows a slight increase in the inhibition efficiency of extract with $0.2 \mathrm{~g} / \mathrm{L}$ $1.0 \mathrm{~g} / \mathrm{L}$ concentrations between the second and third hours. However, a slight decrease in inhibition efficiency with increasing period of immersion occurred (after the third hour) for all inhibitor concentrations except that of $0.6 \mathrm{~g} / \mathrm{L}$. The highest inhibition efficiency value was recorded with the $1.0 \mathrm{~g} / \mathrm{l}$ concentration of the extract at the third hour of experiment.

\section{Effect of concentration on weight loss}

Figure 6 shows that the highest weight loss was recorded with the $0.6 \mathrm{~g} / \mathrm{l}$ concentration while the least was obtained with the $1.0 \mathrm{~g} / \mathrm{l}$ concentration at any given time.

\section{CONCLUSION}

From the results obtained, Mangifera indica seed extract acted as a good inhibitor for the corrosion of aluminum metal in $0.5 \mathrm{M}$ hydrochloric acid medium. The highest inhibition efficiency was obtained with the $0.4 \mathrm{~g} / \mathrm{L}$ concentration for the prolonged test and $1.0 \mathrm{~g} / \mathrm{L}$ concentration of the extract for the rapid test. The extract did not perform well as an inhibitor at the $0.6 \mathrm{~g} / \mathrm{L}$ concentration for both methods.

\section{ACKNOWLEDGEMENT}

I wish to appreciate the efforts of Engr. Owo of Chemical Engineering Department, FUTO, towards the successful completion of this work in the Chemical Engineering Laboratory. I also acknowledge the rigorous research project carried out by Obasi, E. E. in bringing this work to reality.

\section{REFERENCE}

[1] Obot, I, Umoren, S and Obi-Egbedi, N. (2011). Corrosion inhibition and adsorption behaviour of aluminum by extract of Aningeria robusta in $\mathrm{HCl}$ solution: Synergistic effect of iodide ions. Journal of Material and Environmental Science, (pp. $60-71$ ).

[2] Benali, O., Benmehdi, H., Hasnaoui, O., Selles, C. and Salghi, R. (2013). Green Corrosion Inhibitor: Inhibitive action of tannin 


\section{International Journal of Engineering Applied Sciences and Technology, 2020 \\ Vol. 5, Issue 4, ISSN No. 2455-2143, Pages 515-520 \\ Published Online August 2020 in IJEAST (http://www.ijeast.com)}

extract of Chamaerops humilis plant for the corrosion of mild steel13] Ghadal, M. and Alshabana, M. (2017). Study of the in $0.5 \mathrm{M} \quad \mathrm{H}_{2} \mathrm{SO}_{4}$, Journal of Material and Environmental Sciencecorrosion inhibition of carbon steel in $1 \mathrm{M} \mathrm{HCl}$ using extracts (pp.127-138).

[3] Lebrini, M. Robert F and Bros, C. (2011). Alkaloid extracts from Policourea guinesis as corrosive inhibitor for C38 steel in $1 \mathrm{M}$ hydrochloric acid medium. International Journal of Electrochemical Science: SC13553-3567.

[4] Loto, C. (2001). The Effects of Mango Bark and Leaf Extracts Solution Additives on the Corrosion Inhibition of Mild Steel in Dilute Sulphuric Acid - Part 2, Corrosion Prevention and Control

[5] Loto, C.., Mohammed A. and Loto, R. (2003). Inhibition evaluation of mango juice extracts on the corrosion of mild steel in HCI. Corrosion Prevention and Control, (pp.107-118).

[6] Ugi, B., Ekerete, J. Ikeuba I. and. Uwah, I. (2015). Mangifera indica Leave Extracts as Organic Inhibitors on the Corrosionof Zinc Sheet in $5 \mathrm{M} \mathrm{H}_{2} \mathrm{SO}_{4}$ Solution, Applied Science and Environmental .Management, (pp.145 - 152)

[7] Ramezanzadeh, M Bahlakeh, G. Sanae Z. and. Ramezanzadeh. B. (2019). Corrosion inhibition of mild steel in $1 \mathrm{M} \mathrm{HCl}$ solution by ethanolic extract of eco-friendly Mangifera indica (mango) leaves: Electrochemical, molecular dynamics, Monte Carlo and ab initio study, Applied Surface Science, (pp.1058-1077)

[8] Veedu, K., Kalarikkal, T., Jayakumar. N. and Gopalan, N. (2019). Anticorrosive Performance of Mangifera indica Leaf Extract-Based Hybrid Coating on Steel, ACS Omega, (pp. 10176-10184)..

[9] Okoye, O., Edeh, J. and. Obi, A. (2015). Corrosion Inhibition Properties of Mangifera indica Seed Extract on Mild Steel Umudike, Journal of Engineering and Technology, (pp. 137 -144).

[10] da Rocha, J., Gomes, J. and. d'Elia, E. (2014). Aqueous Extracts of Mango and Orange Peel as Green Inhibitors for Carbon Steel in Hydrochloric Acid Solution. Materials Research, (pp. 1581-1587).

[11] Udonne, J. (2015). Corrosion inhibition study of mild steel in hydrochloric acid using Citrus sinensis and Mangifera indica peel extracts, The Journal of Scientific and Engineering Research, (pp.1-7).

[12]. Nwosu, F., Owate, I. and Osarolube, E. (2014). Acidic corrosion Inhibition mechanism of aluminum alloy using green inhibitors, Physics Department, University of Portharcourt, of date palm waste, Department of chemistry, College of Science, Saudi Arabia,

[14] Loto, C., Joseph, O. and. Loto, R. (2015). 'Effect of Vernonia Amigdalina extract and zinc oxide inhibitor on the corrosion of mild steel reinforcement in concrete in $0.2 \mathrm{M}$ $\mathrm{H}_{2} \mathrm{SO}_{4}$ Environment, Journal of Chemical and Pharmaceutical Research, (pp. $871-881$ ). 